\title{
A Absolute Method of Worklife Balance in Public Sector and Private Sector Banks of Hyderabad (Urban) and Hyderabad (Rural) Regions
}

\author{
Ch. V. L. L. Kusuma Kumari, S.Suman Babu
}

\begin{abstract}
Art work-life balance is a hassle of exceptional hassle to many employers and personnel in groups. With contradictory commitments andresponsibilities, within the current, paintings-existence balance has turn out to be anissue of predominance within the workplace. In these days's globalized society, the important factor function of theHuman useful useful resource control is to influence the baseline in their companiespositively, maintain hold of personnel with precious organisation, to broaden employee self-perception. This research study pursuits to apprehend the art work-lifestyles agenda of the employees of Public sector Banks and personal sector Banks of Hyderabad(town) \& Hyderabad (Rural) regions (nearly approximately Public vicinity Banks SBI, Andhra monetary organisation \& monetary organization of India and private region Banks - ICICI, HDFC and AXIS). The test depicts a first firstexcellent affiliation of difficult work-existence stability with the location of the commercial enterprise employer in the case of public vicinity banks and furthermore know-how a significant and correlation amongst artwork-existence stability and the Organizational guidelines.
\end{abstract}

Key Words: artwork-existence stability, place of job, employees, organizational rules.

\section{INTRODUCTION}

$\mathrm{A}_{\mathrm{r}}$ problem has become a stressful problem of no longer the younger business enterprise, who had virtually began out their own family lifestyles know-how moreover the young and center-aged dad and mom who need to offer steady interest to their youngsters who are speedy-growing students/young adults. In a society entire of contradictory responsibilities and commitments, paintings-life balance has become a primary trouble inside the administrative center.

The time period "paintings-lifestyles stability" was first coined over many years in the past in response to the fashion of the 1970s and 1980s while males and females started out out prioritizing artwork and calling targets over family, colleagues, arrange issues, and unwinding works out. There is an industry that has been completely devoted to this field today.

\section{GOALS OF THE STUDY}

The recurring pattern examine study is an undertaking to appreciate the work-life equality of Employees of Public

Revised Manuscript Received on December 22, 2019.

* Correspondence Author

Ch.V.L.L.Kusuma Kumari, Research Scholar

Hyderabad Business School, GITAMS, Hyderabad

Dr. S.Suman Babu, Assistant Professor, Hyderabad Business School,

GITAMS, Hyderabad
Sector Banks and Private Sector Banks of Hyderabad (Urban) and Hyderabad (Rural) region(with reference to Public Sector banks SBI, Andhra Bank and Bank of India and Private Sector banks ICICI, HDFC and Axis).

The present examination is arranged with the going with goals:

1. To consider the relationship of existing legitimate game plans with the work-life leveling of employeesof Public Sector Banksof Hyderabad (Urban) and Hyderabad (Rural) area

2. To ponder the relationship of existing progressive methodologies with the work-life evening out of agents of Private Sector Banks of Hyderabad (Urban) and Hyderabad (Rural) zone

\section{HYPOTHESIS OF STUDY}

To look for after the proposed assessment, the going with speculations are surrounded and their authenticity attempted through research techniques:

$\mathrm{H} 01=$ There is no significantassociation between definitive game plans and work-life balance.

$\mathrm{H} 11=$ There is asignificant connection between progressive methodologies and work-life balance

\section{METHOdOLOGY OF STUDY}

Basic Data:

The basic data for this examination is accumulated from Employees of PSU Banks and Private Sector Banks. A case of 520 from all of the Location for instance Hyderabad (Urban) and Hyderabad (Rural) was assembled. The grouping was done through near and dear gathering and study procedure eventually.

Assistant Data:

Wellsprings of assistant data for this assessment are: Websites, Articles, Magazines, Publications, and Annual Reports, Journals similarly as Thesis and Dissertations and various endeavors on the equal or related point.

Assessing Method

Non-Probability Convenience assessing was used in this assessment.

Test Size Distribution: 
A Absolute Method of Worklife Balance in Public Sector and Private Sector Banks of Hyderabad (Urban) and Hyderabad (Rural) Regions

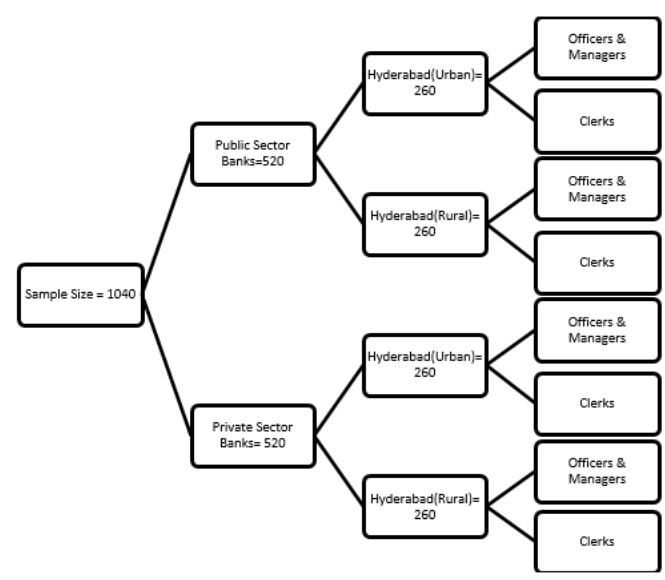

Analysis of Data

The data is analyzed using the following statistical techniques.
1. Frequency Distribution
2. Microsoft Excel-2007
3. SPSS
4. Z-test
5. ANOVA

\section{LIMITATIONS OF STUDY}

Researchers use different concepts to measure balance. The results of this study are a reflection of these shortcomings. The study is restricted to understand the perceptions of employees of the Hyderabad (Urban) \& Hyderabad (Rural) region. The study findings cannot be generalized, due to the fact the trends and paintings way of existence of the banks can be awesome from worker to an employee on the identical degree in the unique components of the us of a.

\section{DATA ANALYSIS}

For the study on Work-Life Balance, Employers' Contribution provided by the respondents was collected by using a Likert scale as a device for 12 statements given under. Responses given for each statement had been recorded and categorized. information after type is obtainable in the desk:

Table: Distribution of Sample for Public Sectors Banks: Factors indicating Organizational Policies

\begin{tabular}{|c|c|c|c|c|c|}
\hline Organizational Policies & 1 & 2 & 3 & 4 & 5 \\
\hline Work Practices & 75 & 88 & 111 & 146 & 100 \\
\hline Work Environment & 80 & 85 & 96 & 139 & 120 \\
\hline Employee Morale & 76 & 75 & 136 & 154 & 79 \\
\hline Job Responsibilities & 78 & 84 & 136 & 136 & 86 \\
\hline Managing employee-employer relations & 78 & 86 & 100 & 139 & 117 \\
\hline Regular Meetings & 72 & 78 & 93 & 150 & 127 \\
\hline Fringe Benefits & 83 & 84 & 107 & 155 & 91 \\
\hline Social Events & 101 & 134 & 120 & 88 & 77 \\
\hline Contribution to family welfare & 107 & 147 & 102 & 98 & 66 \\
\hline Overall organization rating & 67 & 69 & 73 & 176 & 135 \\
\hline
\end{tabular}

(Source: Researcher's Analysis)

The responses given were rated in the following manner:

$1=$ Very Good

$2=$ Good

$3=$ Neutral

$4=$ Poor

$5=$ Very Poor

After rating the responses, the mean and standard deviation of the same were

Table: Indicating mean \& standard deviation of factors indicating Organizational Policies

\begin{tabular}{|l|l|l|l|l|l|}
\hline & N & Min & Max & Mean & SD \\
\hline Org. Policies & 520 & 25 & 100 & 69.98 & 12.94 \\
\hline
\end{tabular}

(Source: Researcher's Analysis)

The above table indicates that the mean score of Employers' contribution is 69.98 and Standard Deviation is 12.94. All 520 responses are classified into three groups. Respondents having a score below 25.00 are classified into - Low levelof Stress. Respondents of the score between 25.00 and 100.00 are classified into -Medium level of Stress. Respondents of score above 100.00 are classified into - High level of Stress. The Levels of Job Satisfaction of an individual has been tabulated in the following manner:
Table: Range of factors indicating Organizational Policies

\begin{tabular}{|l|l|l|l|l|}
\hline $\begin{array}{l}\text { Rang } \\
\mathrm{e}\end{array}$ & $\begin{array}{l}\text { Freque } \\
\text { ncy }\end{array}$ & $\begin{array}{l}\text { Perce } \\
\text { nt }\end{array}$ & $\begin{array}{l}\text { Valid } \\
\text { Perce } \\
\text { nt }\end{array}$ & $\begin{array}{l}\text { Cumulat } \\
\text { ive } \\
\text { Percent }\end{array}$ \\
\hline Low & 83 & 16 & 16 & 16 \\
\hline $\begin{array}{l}\text { Medi } \\
\text { um }\end{array}$ & 385 & 74 & 74 & 90 \\
\hline High & 52 & 10 & 10 & 100 \\
\hline Total & 520 & 100 & 100 & \\
\hline
\end{tabular}

(Source: Researcher's Analysis) 
Table: Distribution of Sample for Private Sector Banks: Factors indicating Organizational Policies

\begin{tabular}{|l|l|l|l|l|l|}
\hline Organizational Policies & 1 & 2 & 3 & 4 & 5 \\
\hline Work Practices & 71 & 75 & 115 & 153 & 106 \\
\hline Work Environment & 82 & 89 & 97 & 121 & 131 \\
\hline Employee Morale & 74 & 75 & 127 & 167 & 77 \\
\hline Organizational Structure & 68 & 86 & 105 & 164 & 97 \\
\hline Job Responsibilities & 69 & 84 & 154 & 128 & 85 \\
\hline Managing employee-employer relations & 72 & 79 & 114 & 134 & 121 \\
\hline Regular Meetings & 79 & 81 & 95 & 141 & 124 \\
\hline Remuneration & 86 & 83 & 91 & 141 & 119 \\
\hline Fringe Benefits & 83 & 84 & 107 & 155 & 91 \\
\hline Social Events & 101 & 134 & 120 & 88 & 77 \\
\hline Contribution to family welfare & 124 & 142 & 109 & 87 & 58 \\
\hline Overall organization rating & 86 & 53 & 75 & 164 & 142 \\
\hline
\end{tabular}

(Source: Researcher's Analysis)

The responses given were rated in the following manner:

$$
\begin{aligned}
& 1=\text { Very Good } \\
& 2=\text { Good } \\
& 3=\text { Neutral } \\
& 4=\text { Poor } \\
& 5=\text { Very Poor }
\end{aligned}
$$

After rating the responses, the imply and trendy deviation of the identical have been calculated, that are offered inside the following table: desk: Indicating imply \& favored deviation of things indicating Organizational policies

\begin{tabular}{|l|l|l|l|l|l|}
\hline & N & Min & Max & Mean & SD \\
\hline & 5 & & & & \\
Org. & 2 & & & & \\
Policies & 0 & 25 & 100 & 67.32 & 29.6 \\
\hline
\end{tabular}

(Source: Researcher's Analysis)

The above table indicates that the mean score of Employer's Contribution is 67.32 and Standard Deviation is 29.6. All 520 responses are classified into three groups. Respondents having a score below 25.00 are classified into - Low levelof Stress. Respondents of the score between 25.00 and 100.00 are classified into - Medium level of Stress. Respondents of score above 100.00 are classified into - High level of Stress. The Levels of Job Satisfaction of an individual has been tabulated in the following manner:

Table: Levels of WLB: Location

\begin{tabular}{|l|l|l|l|}
\hline WLB Range & Location & Hyderabad (Rural) & Total \\
\hline & Hyderabad(Urban) & 72 & \\
\hline Low & 19 & 170 & 91 \\
\hline Medium & 202 & 18 & 372 \\
\hline High & 39 & $\mathbf{2 6 0}$ & 57 \\
\hline Total & $\mathbf{2 6 0}$ & & \\
\hline
\end{tabular}

(Source: Researcher's Analysis)
Table: Range of factors indicating Organizational Policies

\begin{tabular}{|l|l|l|l|l|}
\hline $\begin{array}{l}\text { Rang } \\
\text { e }\end{array}$ & $\begin{array}{l}\text { Freque } \\
\text { ncy }\end{array}$ & $\begin{array}{l}\text { Perc } \\
\text { ent }\end{array}$ & $\begin{array}{l}\text { Vali } \\
\text { d } \\
\text { Perc } \\
\text { ent }\end{array}$ & $\begin{array}{l}\text { Cumula } \\
\text { tive } \\
\text { Percent }\end{array}$ \\
\hline Low & 91 & 18 & 18 & 18 \\
\hline $\begin{array}{l}\text { Medi } \\
\text { um }\end{array}$ & 371 & 71 & 71 & 89 \\
\hline High & 58 & 11 & 11 & 100 \\
\hline Total & $\mathbf{5 2 0}$ & $\mathbf{1 0 0}$ & $\mathbf{1 0 0}$ & \\
\hline
\end{tabular}

(Source: Researcher's Analysis)

\section{TESTING OF HYPOTHESIS for Public sector Banks}

\section{WLB \& Type of Location}

$\mathrm{H} 01=$ there can be no significant association among artwork-lifestyles stability and area

$\mathrm{H} 11=$ there may be a significantassociation amongst art work-life balance and area

The affiliation amongst paintings-life stability and the location i.e. Hyderabad (metropolis) and Hyderabad (Rural) is examined the use of Chi-square and t-take a look at. The consequences mean that the null hypothesis is rejected and the alternative speculation is regular. consequently, there may be a significantassociation between paintings-life stability and location. 


\section{A Absolute Method of Worklife Balance in Public Sector and Private Sector Banks of Hyderabad (Urban) and Hyderabad (Rural) Regions}

The above table indicates that out of 520 respondents, 91 belong to the Low level of WLB, 372 respondents belong to the Medium level of WLB and remaining 57 respondents belong to the High level of WLB.

Out of 91 respondents, 19 are from Hyderabad (Urban) and 72 are from Hyderabad (Rural) region. Out of 372 respondents, 202 are from Hyderabad (Urban) and 170 respondents belong to Hyderabad (Rural) region. And out of 57 respondents, 39 are from Hyderabad (Urban) and 18 respondents are from Hyderabad (Rural) Location.

The above information can be represented using a bar diagram as follows:

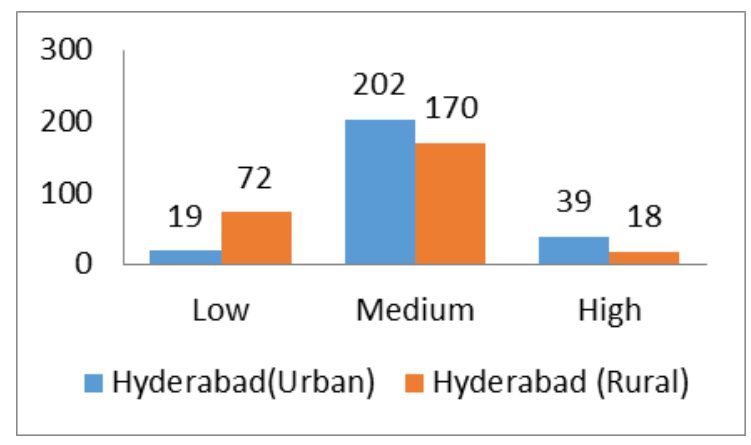

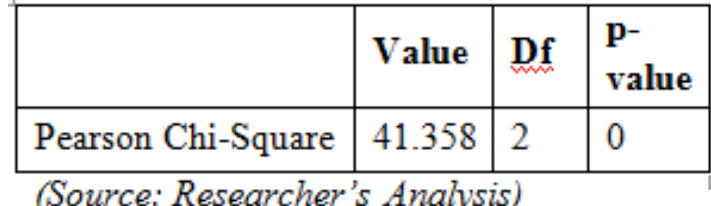

The above table shows thatthe p-price is 0.00 that is much much less than the identical vintage price zero.05. as a result, the null hypothesis is rejected and the exchange hypothesis is time-commemorated.

Conclusion: there can be a significantassociation between WLB and location.

\section{RESULTS OF Z-TEST:}

Table: Indicating Mean \&Std. Deviation for Location

\begin{tabular}{|l|l|l|l|}
\hline Location & N & Mean & SD \\
\hline Hyderabad(Urban) & 260 & 69.8 & 9.78 \\
\hline Hyderabad (Rural) & 260 & 63.44 & 14.69 \\
\hline Total & 520 & 66.62 & 12.9 \\
\hline
\end{tabular}

(Source: Researcher's Analysis)

The above table indicates that the mean WLB score for Hyderabad (Urban) is 69.80 whereas the mean WLB score for clerks is 63.44 .

Using the above results, $z$-test is as follows:

Table:z test:
Results of Chi-square:

Table: Chi-Square Test: Location

\begin{tabular}{|l|l|l|l|l|l|l|l|l|}
\hline Location & N & Mean & SD & $\begin{array}{l}\text { SE of Diff } \\
\text { of Means }\end{array}$ & $\begin{array}{l}\text { Diff of } \\
\text { Means }\end{array}$ & $\begin{array}{l}\text { Cal } \\
\text { z-value }\end{array}$ & $\begin{array}{l}\text { Table } \\
\text { z-value }\end{array}$ & $\begin{array}{l}\text { Null } \\
\text { hypothesi } \\
\text { s }\end{array}$ \\
\hline Hyderabad(Urban) & 260 & 69.8 & 9.78 & 1.094 & -6.36 & -5.811 & 1.96 & Rejected \\
\cline { 1 - 4 } & 260 & 63.44 & 14.69 & & & & \\
\hline
\end{tabular}

(Source: Researcher's Analysis)

The above table shows that, calculated t- value $(-5.811)$ falls outside the region of Standard normal variate tabulated $\mathrm{z}$ value (1.96). Hence, the null hypothesis is rejected.

Conclusion: There is a significant association between Work-Life Balance \& Location in the case of Public Sector Banksof the Hyderabad (Urban) and the Hyderabad (Rural) regions.

TESTING OF HYPOTHESIS for Private sector Banks

\section{WLB \& Type of Location}

$\mathrm{H} 01=$ there may be nosignificant affiliation between paintings-existence stability and vicinity

$\mathrm{H} 11=$ there may be a significantassociation among paintings-lifestyles stability and place

The affiliation between work-life balance and the area i.e. the Hyderabad (urban) and the Hyderabad (Rural) region is examined the usage of Chi-square and t-test. The outcomes indicate that the null speculation is common and the alternative speculation is rejected. Consequently, there's no massive association between paintings-existence stability and the area.

Table: Levels of WLB: Location

\begin{tabular}{|l|l|l|l|}
\hline WLB Range & Location & Total \\
\hline & Hyderabad(Urban) & Hyderabad (Rural) & \\
\hline Low & 36 & 50 & 86 \\
\hline Medium & 181 & 183 & 364 \\
\hline High & 43 & 27 & 70 \\
\hline Total & $\mathbf{2 6 0}$ & $\mathbf{2 6 0}$ & \\
\hline
\end{tabular}

(Source: Researcher's Analysis) 
The above table indicates that out ofthe 520 respondents, 86 belong to the Low level of WLB, 364 respondents belong to the Medium level of WLB and remaining 70 respondents belong to the High level of WLB. Out of the 86 respondents, 36 are from the Hyderabad (Urban) and 50 are from the Hyderabad (Rural) region. Out of 364 respondents, 216 are from the Hyderabad (Urban) and 148 respondents belong to the Hyderabad (Rural) region. Out of 70 respondents, 43 are from the Hyderabad (Urban) and 27 respondents are from the Hyderabad (Rural) Location.

The above information can be represented using a bar diagram as follows:

\section{WLB and Location}

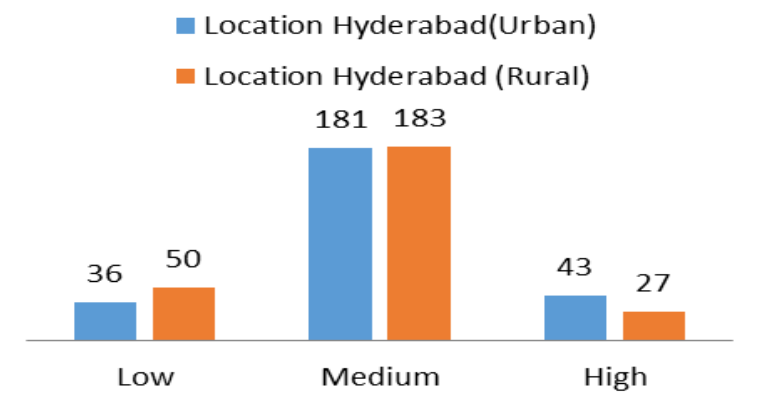

Results of Chi-square:

Table: Chi-Square Test: Location

\begin{tabular}{|l|l|l|l|}
\hline & Value & Df & p-value \\
\hline Pearson Chi-Square & $\begin{array}{l}5.947 \\
2\end{array}$ & 2 & 0.0511 \\
\hline
\end{tabular}

(Source: Researcher's Analysis)

The above table indicates that the p-value is 0.0511 which is greater than the standard value 0.05 . Hence, the null hypothesis is accepted and the alternate hypothesis is rejected. Conclusion: There is no significant association between WLB and Location.

\section{RESULTS OF Z-TEST:}

Table: Indicating Mean \& Std. Deviation for Location

\begin{tabular}{|l|l|l|l|l|l|l|l|l|}
\hline Location & N & Mean & SD & $\begin{array}{l}\text { SE of } \\
\text { Diff of } \\
\text { Means }\end{array}$ & $\begin{array}{l}\text { Diff of } \\
\text { Means }\end{array}$ & $\begin{array}{l}\text { Cal } \\
\text { z } \\
\text { ralue }\end{array}$ & $\begin{array}{l}\text { Table } \\
\text { z- } \\
\text { value }\end{array}$ & $\begin{array}{l}\text { Null } \\
\text { lypothesis }\end{array}$ \\
\hline $\begin{array}{l}\text { Hyderabad } \\
\text { (Urban) }\end{array}$ & 260 & 67.3 & 26.25 & 2.075 & 1.1 & 0.530 & 1.96 & Accepted \\
\cline { 1 - 1 } $\begin{array}{c}\text { Hyderabad } \\
\text { (Rural) }\end{array}$ & 260 & 68.4 & 20.75 & & & & & \\
\hline
\end{tabular}

(Source: Researcher's Analysis)

The above table indicates that the mean WLB score for the Hyderabad (Urban) is 67.3 whereas the mean WLB score for the Hyderabad (Rural)region is 68.4 .

Using above results, the $\mathrm{z}$-test is as follows:

Table: z-test:

\begin{tabular}{|l|l|l|l|}
\hline Location & N & Mean & SD \\
\hline Hyderabad(Urban) & 260 & 67.3 & 26.25 \\
\hline Hyderabad (Rural) & 260 & 68.4 & 20.75 \\
\hline Total & 520 & 67.85 & 23.5 \\
\hline
\end{tabular}

(Source: Researcher's Analysis)
The above table shows that the calculated t- value (0.53) falls within the region of the Standard normal variate tabulated $\mathrm{z}$ value (1.96). Hence, the null hypothesis is accepted.

Conclusion: There is no significant association between Work-Life Balance \& Locationin the case of Private Sector Banksof Hyderabad (Urban) and Hyderabad (Rural) regions.

\section{FINDINGS}

\section{Public sector Banks}

There is a significant association between Work-Life Balance of Employees and location. The mean score of Employees of the Hyderabad (Urban) region is 69.8 and the Employees of Hyderabad (Rural) region is 63.44. Hence,the Employees belonging to the Hyderabad (Urban) region have better Work-Life Balance when compared to the Hyderabad (Rural) region.

\section{Private Sector Banks}

There is no significant association between Work-Life Balance of Employees and location. The mean score of Employees of Hyderabad (Urban) region is 67.3 and the Employees of Hyderabad (Rural) regionis 68.4, which does not indicate any significant difference.

\section{SUGGESTIONS}

Lessened working days: Working hours may be extended to reduce the number of working days in regions where considerable numbers of employees are non-locals. This can help them spend quality time with family and maintain a work-life balance.

Time Management: This is a good solution in general to reduce work-life conflict in employees' lives. By prioritizing tasks and proper planning, free time can be taken out and utilized for other purposes which can help to overcome stress.

\section{CONCLUSION}

Art work-life stability is a massive region of Human resource control. The workload and private lifestyles imbalance can motive strain. effective paintings-life balance rules can lead to asatisfied and inspired team of workers and thereby improved purchaser offerings. So, groups need to deliver hobby to worker wishes and guide them to balance their artwork and private lifestyles.

\section{REFERENCES}

1. T. D. (2001), Family-supportive work environments: The role of organizational perspectives, Journal of Vocational Behavior, Vol.58, pp.414-435.

2. Booth, A. L. and Van Ours, J. C. (2009), Hours of Work and Gender Identity: Does Part-time Work Make the Family Happier? Economica, 76: 176-196.

3. Brough, P., Holt, J., Bauld, R., Biggs, A. and Ryan C. (2008). -The ability of work-life balance policies to influence key social/organizational issues, Asia Pacific Journal of Human Resources, Vol. 46. Issue 3, pp. 261-274.

4. Buddhapriya, S. (2009), Work-Family Challenges and Their Impact on Career Decisions: A Study of Indian Women Professionals. The Journal for Decision Makers, Vol. 34, pp. 31-45.

5. Goyal K.A. (2015), Issues and Challenges of Work-Life Balance in Banking Industry of India, Pacific Business Review International Journal, Vol.8, pp.113-118. 
A Absolute Method of Worklife Balance in Public Sector and Private Sector Banks of Hyderabad (Urban) and Hyderabad (Rural) Regions

6. Edwards, J.R., Rothbard, N.P. (2000), "Mechanism linking work and family: clarifying the relationship between work and family constructs", Academy of Management Journal, Vol. 25 pp.178-99.

7. Fleetwood, S.(2007), Why work-life balance now?, International Journal of Human Resource Management, Vol.1. Issue 3, pp.387-400.

8. Moore, Fiona (2007), Work-life balance: Contrasting managers and workers in an MNC\|, Employee Relations. Vol.29. Issue 4, pp. 385-399.

9. Saneesh Michael (2008), How to balance work and life? www.Living.one.india.in/do-it-yourself/ personal/2008 work-life-balance-family-life.

\section{AUTHORS PROFILE}

Ch.V.L.L.Kusuma Kumari, Research Scholar

Hyderabad Business School, GITAMS, Hyderabad

Dr. S.Suman Babu, Assistant Professor, Hyderabad Business School, GITAMS, Hyderabad 